\title{
National Income Accounting and Economic Welfare: The Concepts of GNP and MEW
}

\author{
by KENNETH STEWART
}

HE MOST comprehensive indicator of economic performance in the nation in a given year is gross national product (GNP), Changes in GNP reflect both changes in prices and changes in the physical volume of output. GNP adjusted for price level changes is generally accepted as a reliable indicator of growth in the nation's total production and is used by economic analysts to indioate whether the economy is expanding or contracting. Policymakers use GNP data, along with other measures of economic activity, in the formulation and subsecuent evaluation of stabilization policy.

A growing GNP is generally associated with expanding opportunities for employment and an increasing amount of material welfare. Economic policy facilitating GNP growth is formulated, in part, as a means of reducing both unemployment and poverty. But a growing GNP has also been accompanied by urban decay and pollution, which are not accounted for in national income data. Critics of economic growth, as measured by national income data, argue that such data tend to emphasize the growth of material welfare while ignoring what is happening to the "quality of life" or "social welfare." GNP has been growing, but what has been happening to total welfare?

William Nordhaus and James Tobin recently proposed an indicator to obtain a measure of "economic welfare" or "standard of living" to complement GNP." This indicator, referred to as "Measure of Liconomic

1William Nordhans and Janes Tobin, "Is Growth Obsolete?" Economic Growth, Fiftiet Anniversary Colloquinm, Vol. 5 (New York: National Burean of Economic Research, 1972).
Welfare" (MEW), would modify the present GNP measure primarily in three ways: 1) by subtracting estimates of certain costs or "bads", such as pollution, from the national income total; 2) by excluding some services, such as police services, since it is possible that increased police budgets to combat rising crime do not indicate an increase in welfare; and 3) by adding to GNP some activities, such as household activities (housework, home repairs, etc.) and leisure, which are not included in the GNP total.

This article discusses the Nordhans-Tobin measure of economic welfare. Since they use GNP as a point of departure, the concept of GNP is reviewed in the first part of this paper and then compared with the proposed MEW concept.

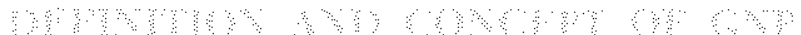

Gross national product can be defined as the market value of domestic current final output. ${ }^{2}$ It provides a measure of the nation's aggregate economic activity income or output - measured in terms of current market prices over a given period of time, ustally a year.

Two methods can be used in measuring the nation's income or output - the income approach and the expenditure approach. The income approach determines gross national income by totaling the various income shares of the factors of production, such as compensation of employees, rental income, proprietors' income,

\footnotetext{
tFor further discussion of the $\mathrm{ONP}$ concept, see Armen $A$. Alchian and William $R$. Allen, Univessify Economics, $3 \mathrm{rd}$ ed. (Belmont, Califonia: Wadsworth Publishing Company, Inc., 1972), expecially up. 529-533.
} 
net interest, and corporate profits (and adding in an allowance for depreciation, indirect business taxes, and other smaller items). The expenditure approneh determines the current value of production basically by totaling all expenditures for final goods and services based on type of purchase and expenditure (plus the net change in business inventory). Expenditures in the national income accounts are classified as personal consumption expenditures, gross private domestic investment, government purchases of goods and services, and net exports. The two approaches provide approximately the same total, for expenditures on final goods and services provide income to the factors of production which produced these items.

In general, nonmarketed goods, such as goods and services prodnced and consumed by the household (which would include meals prepared in the home and home repairs) are not included as part of the nation's measured income. The exclusion of such productive work performed by household members limits the validity of the GNP concept as a measure of the nation's total product. ${ }^{3}$

It also should be stressed that not all market transactions are included in determining $\mathrm{GNl}$, for this

\footnotetext{
A leading authority on national income determination, Simon Kuznets, considered this problem when discussing issues involved in defining national income. He argued against the inclusion of nonmarket activities in general, but cautioned in the interpretation of data which exclude such activities: "The national income estimator nust choose between comprehensive definition - with the consequence that large sectors of the econony either cannot be measured on a continuous basis or cannot be inciuded with more precisely measurable sectors because the errors are so entrmous and a natrower definition that confines economic activities to those marketbound - for which tolerably reliable estimates can be made. In current national income measurement in this country, the decision is usually in favor of the second alternative. And it finds support in the argument that the activities so segregated for measurement are the ones subject primarily to economic criteria and rationale; whereas those that are not directed at the market are much more a part of life in general. One may and does discharge a housekeever for inefficiency in managing a household, but by itself this is rarely a ground for divorce ....

"The national income estimator cannot do much about such omissions, since searcity or lack of data is inherent in the nature of the omitted treas. But in interpreting national income movenents in tems of satisfying consumers' wants, the limifation of national income largely to noncasual marketbound activities must be stressed. In this country as in many others where the market is always being extended, the relative importance of the household as a source of consumer goods is declining. Many activities formerly performed by the housewife or other members of the family and not measured (baking, sewing, canning, etc.) have progressively been taken over by business enterprises and gone into market-bound activities; other household functions have vanished withont leaving a direct substitute in business activity. Hence, national income totals tend to exaggerate the tipward movement in the supply of goods to consimers, if such supply is conprehensively defined as coming from both market-bound and family activities." [Simon Kuznets, National Income: A Summany of Findings (New York: National Bureal of Economic Research, Inc., 1946), wp. 124-125.]
}

would involve double-counting. Final products are not normally resold; intermediate products are resold in some form. For example, flour sold by a miller to a baker is resold in the form of bread. To count the flour sold by the miller and the bread sold by the baker as part of GNP would involve double-counting the value of the flour. ${ }^{4}$

Market transactions involving the exchange of wealth or claims to wealth are also excluded in the determination of GNP. Exchange of stocks on the stock market and exchange of bonds in the securities markets only shift ownership of claims to existing assets from one person to another. For the most part, the sale of a used car has a similar effect. In both cases, no increase in production or productive capacity is $\mathrm{di}^{-}$ rectly related to the exchange of these assets. Included in GNP, however, are some of the dealer costs associated with these transactions. These costs include, among other things, the salaries and the commissions of the stock and security brokers and used car salesmen, since they provide a current service in the exchange of existing assets. In determining what is included in GNP, the emphasis is on current economic activities which are "productive" in the sense of creating income. A sale of a new car would be included in GNP for this is an end item of current productive activity.

The concept of GNP then necessarily implies selection of what one considers "productive activity". In determining GNP, one must use some criteria of production which are based on an implicit or explicir value judgment. To quote Simon Kuznets, a pioneer in developing national income accounting concepts:

... if no criteria of social productivity are used, national income becomes a mechanical total of all net receipts of individuals and business agencies, regardless for what activity or even whether there is any activity. It would include the compensation of robbers, murderers, drug peddlers, and smugglers, differential gains from the transfer of claims, and pure transfers such as gifts and contributions, which, in the absence of a productivity criterion, cannot be distinguished from payments for services. Such a judgmentless estimate would be of little use, since, to measure all market transactions, some gross rather

\footnotetext{
At the end of an accounting period, any increase in the inventory of raw materials (or intermediate products) is included as part of the total product of that period, Doublecounting can be avoided by totaling only the market value of "final" products, such as bread (plus an allowance for changes in inventories), of by totaling the sum of the "value added" by all firns. Value added by a firm equals the narket revenues received by the firm minus the cost of the raw materials. In the above example the value added by the baker would be the revenues received through the sale of the bread minus the cost of the flour and other ingredients.
} 
than net total is requisite. It would measure neither the positive contribution of the country's economic system to the needs of its members for purposes of consumption or capital formation nor the sum total of what the inhabitants of the country think their income is. ${ }^{5}$

Kuznets favored a policy of making any underying "scheme of values or social philosophy" explicit and allow it to guide the selection of the data.

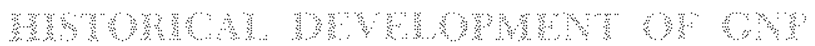

The concept of "production" or "productive activity" in the measurement of national income has been given different meanings by various writers and govern. ments. In The Weath of Nations, which was frst published in 1776, Adam Smith distinguished productive activities as the making of material goods only; all services, such as those provided by churchmen, lawyers, doctors, musicians, etc, were considered unproductive since "the work of all of them perishes in the very instant of its production."

Smith's concept of productivity was perpetuated in the writings of David hicardo and John Stuart Mill and formed the basis of the primary national income estimates in Fngland and France for nearly a centary. It was not until Afred Marshall identifed the production of goods and services with the ereation of utility in the latter part of the nineteenth cencury that estimators in these two countries retumed to a broader concept of production," This broeder concept included services as well as material commodities in the measurement of output. Tan Marx accopted Smith's distinction, and consequenty, the sovie Union and other communst counties of Lastem Furope adopted a concept of national product that basically excudes all those services which do not contribute to material production.

5Simon Kuznets, National Income and Its Composition, 1919-1938, Vol. 1 (New York: National Bureau of Ecomomic Research, 1941), p. 4, In 197 J, Kunnets received the Nobel Prize in Economics, which was awarded, in part, for his work on developing measurements of national income.

FAdarn Smiti, The Woalth of Nations (New Yotk: The Modern Library, 1937), p. 315.

7 Garlier estinators of national income had used a nore comprehensive production concept. See Intemptional Encyclopedia of the Social Sciences, s.v. "National Income and Rroduct Accounts: Developments wp to World War a."

ssee Moshe Tanovsky, Socid Accombing Sustems (Chicago: Aldine Publishing Company, 1965), pp. 112-115. Other aspects of national income accounting in the Soviet Union are also influenced by the writings of Max. For example, following Marx's theory of ralue, incone is related to only one factor of production - social labor.
In the United States, studies on the measurement of national income appeared in the mid-nineteenth century, and the National Bureau of Economic Research published several studies in the 1920s. Spurred by the economic depression and increasing government involvement in economic affairs, the Depart. ment of Commerce established a National Income Diyision in the late 1930 shich prepared estimates of national income data on an official basis. Oficial figures of U.S. national income and product first appeared in the Survey of Current Business in 1942 and were published in accounting form for the frst time in 1947. Various revisions and refnements have been made since, but the basic structure of national income accounting has not been altered greaty.

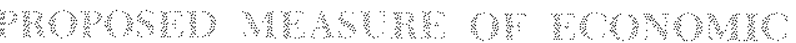 WAPAB}

National income or GNP in the United States today is basically a measure of the market value of goods and services produced during a given period of time. 10 As two proponents of an indicator to measure economic welfare, Willom Nordhaus and James Tobin do not question the usefuness of the GNP data as a measure of production. They consider GNP data indispensable for short-run stabilization policy and for assessing the economy's long-run growth in productive capacty, They do question, however, the usefulness of GNP dafa in eqalueting the growth of economic trelfare.

Nordhaus and Tobiv would he to see the development of a new concept to measure the growth of economic weifare, and their argument for the development of such a concept is as follows:

An obvious shortcoming of GNP is that is an index of production, not consumption. The goal of economic activity, after all, is consumption. Although this is the central premise of economics, the profession has been slow to develop, either conceptually or statistically, a measure of economic performance oriented to consumption, broadly defined and carefully calculated. We have constmoted a primitive and experimental "measure of economic welfare" (MEW), in which we atempt to allow for the more

The present U.S, mational incone accomating system consists of five interlocking acounts: Netional Income and Prounct Account, Personal Hoone and Outlay Account, Government heceipts and Expenditures Aceount, Foreign Transactons Aeconnt, and Gross Savings and Investment Acoonet.

10 The major exceptions concerning production of groods and services which are not marketed but incluted in the meas urement of GNI are estimates of foot produced and consumed on famrs, francial services of compercial banks and other financial intemedianes, and the rencal value for owneracempied houses. 
obvious discrepancies between GNP and economic welfare ${ }^{11}$

To construct their measure of welfare or consumption, Nordhaus and Tobin make several modifications to the existing national income accounts. These modifications fall into three general categories; 1) reclassification of GNP expenditures as consumption, investment, and intermediate; 2) imputation for the services of consumer capital, leisure, and household activities; and 3) correction for some of the disamenities of urbanization and industrialization. ${ }^{12}$

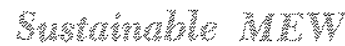

These modifications are shown in Table I. In essence, this table provides various additions and subtractions to gross national product, or net national product, to arrive at what is labeled sustainable MEW.13

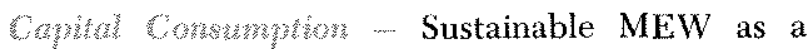
measure of consumption is somewhat similar to the concept of net national product (NNP) as a measure of production. Part of the output included in GNP will be used to repair and replace the existing stock of capital goods. This portion of output is classified as the capital consumption allowance. The stubtraction of the capital consumption allowance from GNP gives NNP. NNP tells us how much current income or production can be consumed consistent with the maintenance of productive capacity or income potential.

In a similar manner, the Nordhaus-Tobin concept of sustainable $\mathrm{MEW}$ provides a measure of "the amount of consumption in any year that is consistent with sustained steady growth in per capita consumption at the trend rate of technological progress." The sustainable MEW concept then considers not only the amount of capital which must be replaced in a period to maintain consumption at the existing level, but also how much additional investment or abstention from consumption in the current period must be made in order to keep consumption per capita growing at some

11 Nordhaus and Tobin, "Is Growth Obsolete?", p. 4.

12Ibid, p. 5 .

13 Another concept, labeled actual MEW, consists only of total consumption for a given perioct and does not take into account any investment expenditures.

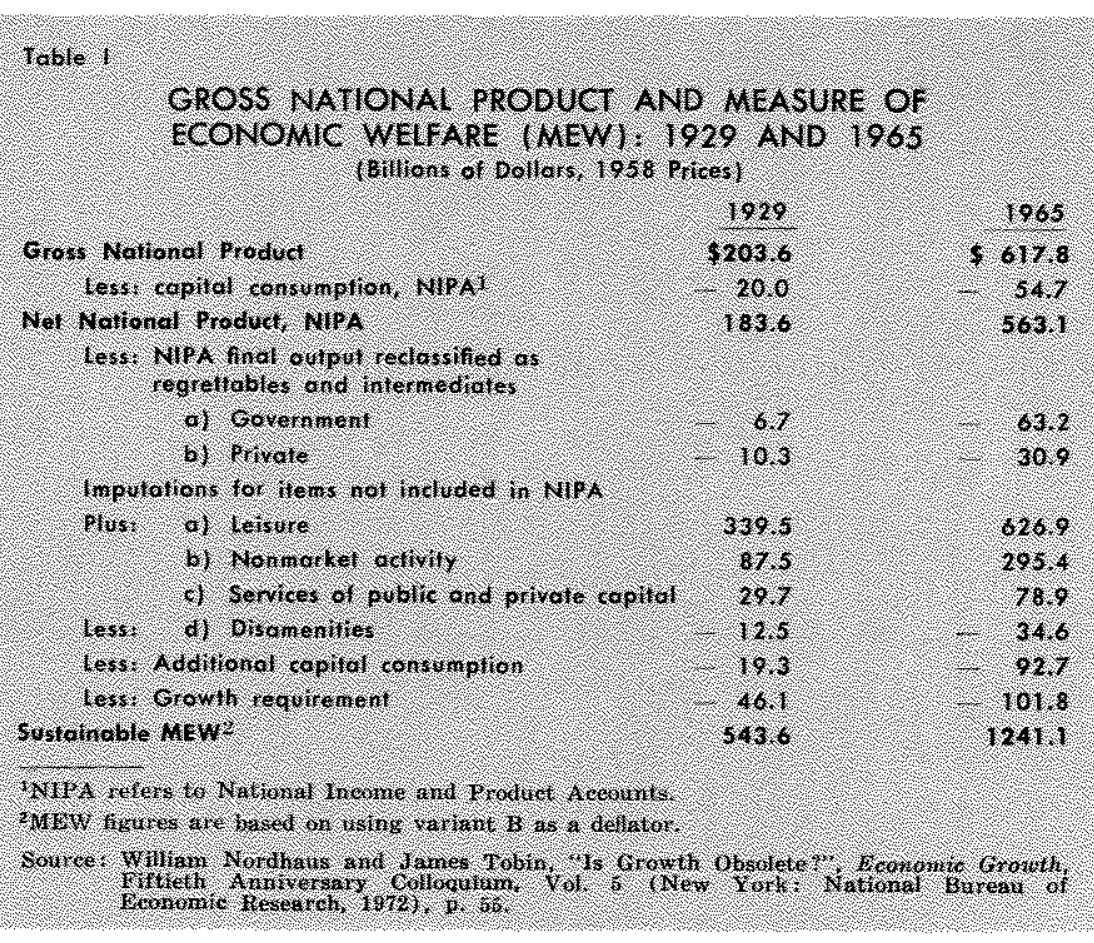

rate which is based on technological progress. ${ }^{14}$ After estimates for both the capital consumption allowance and the growth requirement are made, these estimates are subtracted from GNP.

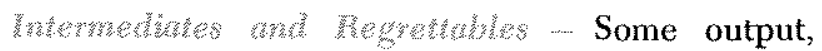
classified as final output for GNP purposes, is reclassified as regrettables and intermediates by Nordhaus and Tobin and is excluded from MEW.

By intermediate product, Nordhaus and Tobin mean "goods and services whose contributions to present or future consumer welfare are completely counted in the values of other goods and services"; ${ }^{15}$ they are "not directly sources of utility themselves but are regrettably necessary inputs to activities that may yield utility."16 Regrettables represent expenditures for national security, prestige, or diplomacy, which in the judgement of Nordhaus and Tobin, do not directly increase the economic welfare of households. No sharp dividing line exists between what is classified as intermediates or regrettables.

Some private expenditures and some Government expenditures are reclassified as intermediate products

\footnotetext{
14Sustainable MEW omits capital expenditures required to maintain the capitaloutput ratio. According to the authors,

"It allows for capital depreciation, for equipping new members of the labor force, and for increasing capital per worker

at the trend rate of productivity change." See Nordhaus and

Tobin, "Is Growth Obsolefe?", pp. 24-25.

lotbid., p. 5 .

1.6Ibid., p. 7 .
} 
or regrettables. Private expenditures, such as personal business expenses and a part of transportation expenditures in the GNP accounts, would be reclassified as intermediate products. A major portion of Government purchases, such as national defense, space research and technology, international affairs and finance, veterans benefits, general government, and civilian safety (police, fire, and correction) are reclassified as regrettables or intermediate products and subtracted from GNP.17

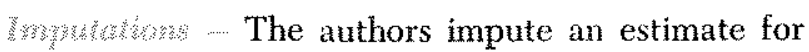
many activities which they feel have a positive or negative effect on social welfare but are not consid. ered in the determination of GNP. Specifically, imputations are made for leisure, nonmarket activity, disamenities, and services of public and private capital.

The most substantial modifications to GNP in obtaining a measure for sustainable MEW are the result of the imputations for leisure and nonmarket activity. Leisure is important to a welfare index, for welfare could rise (consumption of leisure) while GNP falls if employees voluntarily decide to work less. An estimate for nonmarket activity or household production and consumption, such as meals, cleaning, and home repairs, is also added to GNP to obtain MEW.

An estimate for the disamenities of urbanization is subtracted from the GNP data in determining MEW. This estimate considers social costs which are not included in the costs of producing consumption goods and services. ${ }^{18}$ These costs would include pollution, litter, congestion, noise, and insecurity. The estimate

17ibid., p. 7. Kuznets supported the notion that many govermment services should be treated as intermediate goods rather than final product. He argued that services to businesses such as economic legislation and the maintenance of internal and external security is not a direct service to consumers but a cost of maintaining society at large: "a condition of economic production rather than an activity directly yielding final economic goods." He supports the exclusion of these government activities from a country's output by emphasizing that the total which is sought is "that of product, of end-result of activity - not of the volume of activity itself." See Simon Kuznets, "Discussion of the New Department of Commerce Income Series: National Income: A New Version," The Review of Economics and Statistics (August 1948), pp. 156-157. Also see Martin J. Bailey, "Appendix: The Concept of Income," National Income and the Price Level, 2nd ed. (New York: MoGraw-Hill Book Compaty, 1971), pp. 272.274. For an argument against such exclusion see Milton Gilbert, George Jaszi, Edward F. Denison, and Charles F. Schwartz, "Objectives of National Income Measurement: A Reply to Professor Kuznets." The Review of Economics and Statistics (August 1948), pp. $183-189$.

${ }_{18 F}$ For an economic analysis conceming problems of social costs, see R. H. Coase, "The Problem of Social Cost," The Jothnal of Law and Economics (October 1960), pp. 1-44. of these costs is based on the income differentials between large cities and smaller towns and rural areas. Assuming that people can choose residential locations, a portion of the observed income differential can be considered a "disamenity premium" which compensates individuals for unpleasantness associated with living in urban areas. ${ }^{19}$

Services of public and private capital is the last category of imputations for items not included in GNP. The only imputation made for the services of capital in determining GNP is the addition of an estimate for the services received from owner-occupied housing. The MEW concept would extend imputations from capital to include services from Government structures (excluding military) and services from consumer durable goods (under the MEW concept, consumer durables are reclassified as investment goods rather than consumption).

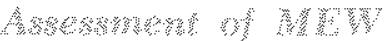

Nordhaus and Tobin state that they are after a measure of consumption, "broadly defined and carefully calculated," but then label this measure a "measure of economic welfare." However, consump" tion and welfare are two different (although related) concepts. Welfare would depend on the amount of total satisfaction one receives from total consumption, and, among other things, would depend asso on the distribution of income. Nordhaus and Tobin realize the problems involved in trying to measure welfare and state that they "cannot... estimate how well in" dividual and collective happiness are correlated with consumption."20 In a comment on the NordhausTobin MEW concept, Robin C. O. Matthews points out that debates in the 1940 s recognized such distinctions between consumption and welfare, and argues that the MEW concept is a measure of consumption not a measure of welfare. ${ }^{21}$

Obtaining reliable estimates of various economic activities which are not included in the national income accounts poses a serious problem in computing MEW. The problems involved in obtaining an accu-

\footnotetext{
19 Acording to the authors, the disamenity premium was about 8 percent of average family disposable income in 1965. Since income differentials have tended to induce migration to urban areas, only a portion of the estimated income differential is subtracted from the CNP accomis as a disamenity premium.

20 Nordhaus and Tobin, "Is Growth Obsolete?", p. 25.

21Robin C. O. Matthews, "Discussion," Economic Growth, Fiftieth Anniversary Colloguium, Vol, 5 (New York: National Beireau of Economic Research, 1972), p. 91.
} 
rate measure of household activities is one of the reasons why such activities are not included in measured GNP. The authors of MEW recognize this problem and attempt to estimate the reliability of various components of MEW.

Nordhaus and Tobin rank the reliability of the components of MEW as having a low error, medium error, high error, or very high error. Data in the national income accounts, such as GNP, are used as a benchmark in determining reliability and are put in the low error category. Components in the very high error category are judged to have about ten times the percentage error of GNP. The imputations for leisure, nonmarket activities, and disamenity fall into this very high error category. The imputations for these activities, however, account for much of the difference between GNP and MEW.

The imputations for leisure and household activities, in terms of constant prices, vary greatly depending on how current price estimates are deflated. The authors obtained constant price estimates of both activities by deflating current prices by a consumption deflator and by deflating by wage rates. The accompanying chart presents three different growth paths of sustainable MEW which depend on how leisure and nonmarket activities are deflated. The authors indicate a preference for variant $B$ which deflates leisure by a wage index and which deflates nonmarket activity by a consumption deflator. ${ }^{22}$

All three variants of $\mathrm{MEW}$ show a positive rate of growth over time, which indicates that real consumption per capita has been increasing. According to variant $\mathrm{C}$, per capita sustainable $\mathrm{MEW}$ grew at a 3.6 percent average compound annual rate from 1929 to 1965, which is slightly faster than the 3.1 percent rate for NNP. In the same time period, variant $B$ grew at a 2.3 percent rate and variant $\mathrm{A}$ at a 1.8 percent rate.

Nordhaus and Tobin have provided an estimate of sustainable consumption over time. After allowing for some of the disamenities of modern production techniques and urban congestion, their estimates show that net consumption has been growing, but probably at a slower rate than total measured output. They recognize that many unsolved problems are posed by their MEW concept, but view the measure as an attempt to obtain an indicator of the growth in economic welfare. Perhaps the intent and conclustons of

22yatiant $A$ dellates both leime and nommarket sotivity by a wage index, and variant $\mathrm{C}$ dethes bot activities by a corismption deflator.

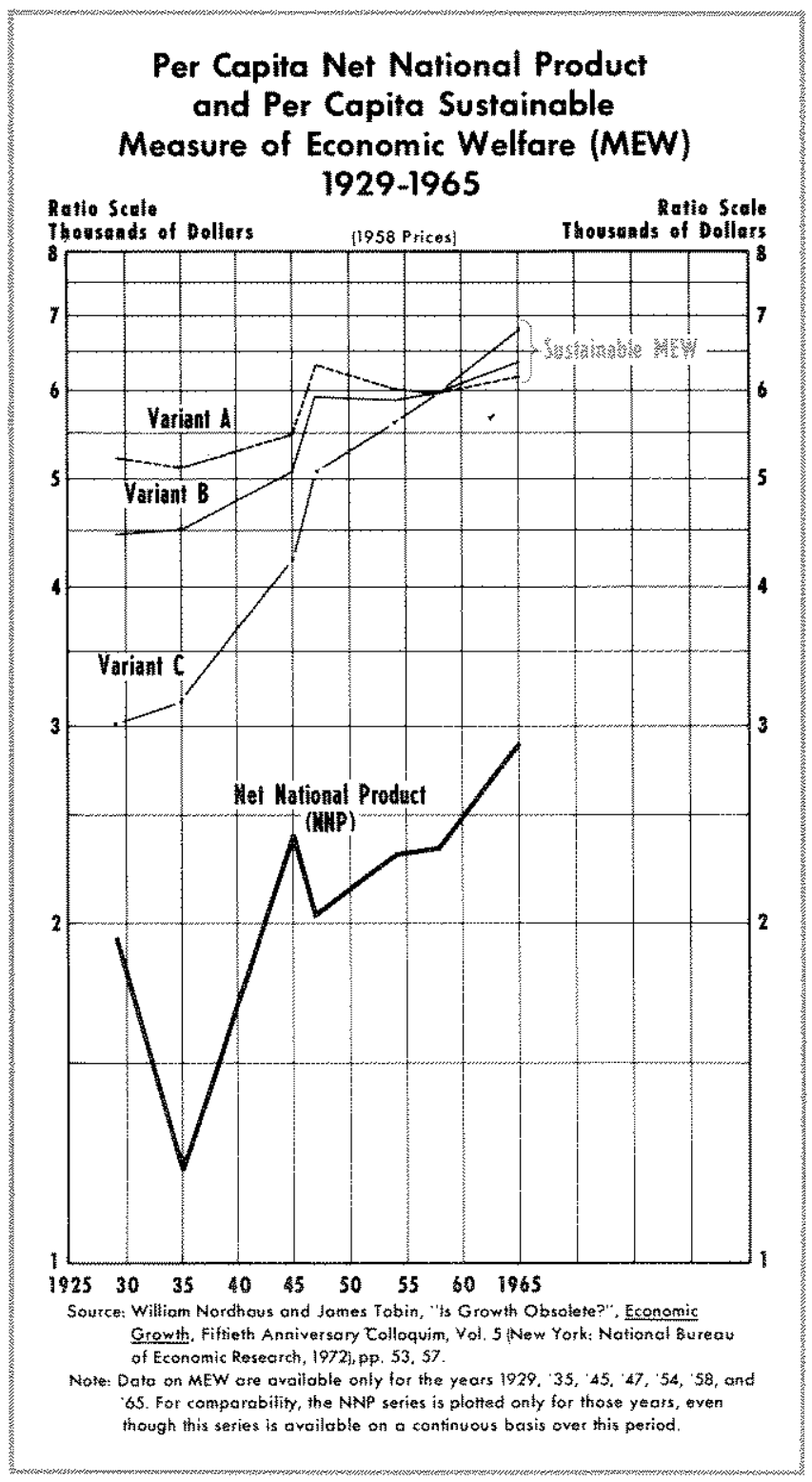

their study can best be summed up by the authors themselves:

We recognize that our proposal is controversial on conceptual and theoretical grounds and that many of the numerical expedients in its execution are dubious. Nevertheless, the challenge to economists to produce relevant welfare-oriented measures seems compelling enough to justify some risk-taking. We hope that others will be challenged, or provoked, to tackle the problem with different assumptions, more refined procedures, and better data. We hope also that further investigations will be concemed with the distribution, as well as the mean value, of a measure of econonic welfare, an aspect we have not been able to consider. ${ }^{23}$

33 Nordhaus and Tobin, "Is Growh Obsoletep", p. 20 


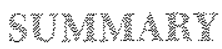

GNP, in general, provides a measure of current production in the United States for which a money income has been received. As a production or income measure, it has been used in forming policy goals for output, employment, and price level changes.

Criticism has been directed against the GNP concept as emphasizing the quantity of goods and services produced while ignoring what is happening to the "quality" of life. Proponents of a new measure to obtain such a quality indicator, or an economic welfare measure, would modify the present national income accounts in several ways. They would subtract from GNP any costs incurred in maintaining clean air and water in the production of goods and services, subtract an estimated cost of urban congestion, subtract expenditures for police and national defense, and include an estimate for the value of nonmarket activities such as household activities and leisure time.

In obtaining their measurement, however, Nordhaus and Tobin have had to resort to a number of crude estimates and rely considerably on their own value judgments concerning the classification of goods and services as consumption or intermediate product. In particular, Nordhaus and Tobin make estinates of many activities, such as household activities, that official national income estimators have avoided because of lack of data. Their judgments concerning what is or is not an intermediate product also play a significant part in this measure. The problem of defining intermediate products is not unique to this measure of consumption, however, as the problem of defining intermediate goods remains an unsettled issue among various national income estimators. For example, Simon Kuznets supports the notion that many governmental services should be treated as intermediate products rather than final products in the national income accounts.

Although the proponents of this new concept refer to it as a measure of welfare, it more accurately pro* vides a broad measure of consumption. A welfare measure would quantify the amount of satisfaction or utility received from consumption and would depend, in part, on the distribution of income. As a measure of consumption, however, the MEW concept attempts to provide an indicator more closely associated with the concept of welfare than that provided by a production measure such as GNP. Unfortunately, in view of the high error content associated with this measure, the proposed MEW concept does little more than break the ice in an attempt to provide an accurate estimate of economic welfare. 